\title{
Gemological ABSTRACTS
}

\section{5}

EDITOR

A. A. Levinson

University of Calgary

Calgary, Alberta, Canada

REVIEU BOARD

Christopher M. Breeding GIA Laboratory, Carlsbad

Maha Calderon

Carlsbad, California

Jo Ellen Cole

Vista, California

Eric Fritz

GIA Laboratory, Carlsbad

R. A. Howie

Royal Holloway, University of London

Alethea Inns

GIA Laboratory, Carlsbad

David M. Kondo

GIA Laboratory, New York

Taijin Lu

GIA Research, Carlsbad

Wendi M. Mayerson

GIA Laboratory, New York

Kyaw Soe Moe

GIA Laboratory, New York

Keith A. Mychaluk

Calgary, Alberta, Canada

Joshua Sheby

GIA Laboratory, New York

James E. Shigley

GIA Research, Carlsbad

Boris M. Shmakin

Russian Academy of Sciences, Irkutsk, Russia

Russell Shor

GIA, Carlsbad

Rolf Tatje

Duisburg University, Germany

Sharon Wakefield

Northwest Gem Lab, Boise, Idaho

\section{COLORED STONES AND ORGANIC MATERIALS}

Gravitationally banded ("Uruguay-type") agates in basaltic rocks-where and when? J. Petránek, Bulletin of Geosciences, Vol. 79, No. 4, 2004, pp. 195-204.

This article suggests new terminology to describe the banding of agates, in order to alleviate the confusion caused by previous descriptors that have no direct correlation to genetic implications. One ambiguous term, Uruguay banding, has been used to describe the straight parallel banding that often occurs in the lower portions of agate-containing vesicles from continental flood basalts. Confusion results because agates with this type of banding are called Uruguay agates, a term that some use to describe any agate from Uruguay.

The author suggests using gravitational banding to refer to all agate textures caused by the force of gravity, which in this case applies to the deposition of relatively thick bands of coagulated silicic acid. The term adhesional banding is suggested as a replacement for terms such as concentric, common, normal, and fortification banding; these all refer to the thin layers of silica that adhere to the vesicle walls and form concentric rings or zones.

Both types of banding commonly occur in agates formed in continental flood basalts from many locations worldwide. Several factors, including the amount and thickness of the lava flow, the temperature and humidity of the region, and the amount of $\mathrm{CO}_{2}$ in the atmosphere, all contribute to the formation of the agate-filled vesicles. A suitable lava thickness will facilitate a slow cooling rate, which allows for the coalescence of numerous gas bubbles into larger vesicles and voids. Conversely, cooler atmospheric temperatures will inhibit vesicle formation. Sufficient rainfall will provide enough water for

This section is designed to provide as complete a record as practical of the recent literature on gems and gemology. Articles are selected for abstracting solely at the discretion of the section editor and his reviewers, and space limitations may require that we include only those articles that we feel will be of greatest interest to our readership.

Requests for reprints of articles abstracted must be addressed to the author or publisher of the original material.

The reviewer of each article is identified by his or her initials at the end of each abstract. Guest reviewers are identified by their full names. Opinions expressed in an abstract belong to the abstracter and in no way reflect the position of Gems \& Gemology or GIA.

(C) 2005 Gemological Institute of America 
hydrothermal circulation within the lava flow to dissolve and transport silica for agate deposition. In combination with abundant rainfall, sufficient atmospheric $\mathrm{CO}_{2}$ will facilitate the formation of carbonic acid. This aids in the chemical weathering of the basalt, releasing the silica and making it available for agate formation. Based on such requirements, the author suggests that the presence of both gravitational and adhesional banding is largely controlled by climate.

The underworld of ivory. R. T. Naylor [thomas.naylor@ mcgill.ca], Crime, Law \&) Social Change, Vol. 42, No. 4-5, 2004, pp. 261-295.

This article offers a detailed history of the demand for and trade in ivory, noting that it was probably the first organic material used for human ornamentation and was perhaps the world's first globally traded commodity, pre-dating gold. Ivory from East Africa began reaching the Roman Empire as early as the 2nd century $\mathrm{BC}$, India from the 7 th century $\mathrm{AD}$, and China shortly afterward. Although elephants also were native to parts of Asia, there they were valued as work animals, while Africans regarded their variety as a destructive pest.

There was little concern about the slaughter of African elephants until the 1970s, when hunting, poaching (in response to soaring prices for ivory), and wars in various African states decimated the herds. Although trade in ivory was banned globally in 1989, demand, principally from Asia, has fueled an underground trading network for the material. The author concludes that the only way to end ivory trafficking effectively is to reduce demand.

$R S$

\section{DIAMONDS}

Angola: Diamond production on the rise. N. Ford, African Business, No. 309, 2005, pp. 54-55.

With the end of Angola's civil war, the country's stateowned diamond administration agency, Endiama, is assuming a wider role in economic growth. Endiama expects the country's yearly diamond production to nearly double by 2007 , to 12 million carats from the 6.5 million carats mined in 2004. With the increased yield, revenues would be an estimated $\$ 2.2$ billion. Part of this increase will come from new production from both alluvial and kimberlite mines. However, illegal mining and smuggling of diamonds is still costing the Angolan government an estimated $\$ 375$ million yearly. The government is attempting to crack down on the 250,000 illegal miners who are responsible for this production.

Colour in diamond-yellow. J. Chapman, Rough Diamond Review, Part I. No. 7, 2004, pp. 42-44. Diamond colour origins. Part II. No. 8, 2005, pp. 23-26.

The origin of color in diamonds is an important research topic in gemology, with both scientific and economic implications. This two-part article describes how impurities and dislocations, and the complex relationship between them, can produce yellow, green, blue, brown, pink, and other colors in diamonds, both naturally and artificially. The general mechanism by which diamonds display bodycolor involves the selective absorption of light by atomic-level defects. Impurities like nitrogen and boron in the diamond lattice can lead to such selective absorption, resulting in yellow and blue coloration, respectively. The tendency for nitrogen in diamond to aggregate into different types of clusters (resulting in A, $\mathrm{N} 3$, and B centers) is explained, as is its effect on color.

In addition to impurity elements, shear stresses on a diamond can distort the lattice or displace atoms in the lattice to cause color. Subjected to this plastic deformation, carbon atoms can be dislodged from the lattice to create vacancies or dislocations, or alter impurity defects, which may create colors such as brown and pink. Radiation can create vacancies leading to pale blue or green diamonds. Other color-causing agents (e.g., nickel) or treatments (e.g., annealing and different types of irradiation) also are discussed, often with respect to synthetic diamonds.

$D M K$

\section{Geosurvey techniques in offshore diamond mining. I.} Stevenson [ian.stevenson@debeersgroup.com] and L. Ricketts, Hydro International, Vol. 8, No. 9, 2004, pp. 26-29.

A $1,400 \mathrm{~km}$ stretch of continental shelf off the west coast of southern Africa hosts the world's largest marine diamond placer deposit. Storm-dominated seas contribute to challenging working conditions. Ultra-high resolution geophysical data obtained with an AUV (autonomous underwater vehicle) are used to improve the geologic understanding of target areas. This enables more precise prediction of diamond concentrations and therefore a reduced cost per square meter of seabed mined.

For survey purposes, the continental shelf is divided into three regions, each requiring mapping and mining strategies best suited to its specific terrain. The inner shelf platform extends from the present-day coastline to about 2 $\mathrm{km}$ offshore and has water depths of 0-30 m. Diamondiferous gravels are concentrated in depressions eroded into the exposed bedrock and are extracted with the use of diver-assisted suction hoses operated from small surface vessels. The inner shelf slope extends $2-5 \mathrm{~km}$ offshore and has water depths of 30-70 m; diamondiferous gravels are located at the base of the sediment layers. The middle shelf region extends $5-150 \mathrm{~km}$ offshore in water $70-200 \mathrm{~m}$ deep, and this is where the majority of offshore mining activity occurs. Here, diamondiferous gravels (usually $<1$ m thick) are mined using a vertical extraction method involving a 7-m-diameter drill or a remote-operated crawler with a suction head. 
Interpreting diamond morphology. V. Afanasiev, N. Zinchuk, V. Sonin, and E. Semenets, Rough Diamond Review, Part I. No. 5, 2004, pp. 30-33; Part II. No. 7, 2004, pp. 26-27.

Typomorphism is the ability of a mineral to reflect its formation conditions by means of its structural, morphological, and/or chemical characteristics. Russian mineralogists have found that such characteristics (e.g., unique morphological and surface features) are of great value in interpreting the original growth, post-growth, and emplacement conditions of diamonds, and for diamond prospecting on the Siberian platform.

Although the primary habit of diamond is the octahedron, modifications to this shape are both common and significant. After growth, the morphology of diamonds may be modified while residing in the medium that formed them and/or during the processes that eventually brought them to the surface. Accordingly, two types of post-growth alteration are recognized: "dry" (anhydrous, without $\mathrm{H}_{2} \mathrm{O}$ ) and "wet" (hydrous, with $\mathrm{H}_{2} \mathrm{O}$ ). Dry morphogenesis is characterized by the rounding of growth layers, the development of parallel striations near octahedral edges, and the formation of inverted trigons. These characteristics reflect post-growth activity in the host medium before entering the transport melt. Wet morphogenesis is characterized by the rounding of octahedral edges leading to dodecahedral (dissolution) forms and occurs within the transport melt.

Post-magmatic conditions, of which mechanical wear during the formation of alluvial deposits is the most important, can also lead to distinctive morphologies. Although mechanical wear only slightly alters morphology, this process is very important from a typomorphic perspective. Mechanical wear is seen in two main forms, striated surfaces and "icicle" features, both of which result from mechanical polishing and abrasion of crystals mainly at their edges and corners. Striated surfaces appear as regular patterns of pitting or wear, whereas icicle features refer to smooth surfaces (with the appearance of ice) that suggest such diamonds are very old and may have been through numerous cycles of erosion and deposition.

Typomorphic features (including those obtained by infrared spectroscopy and trace-element analysis) offer the potential for determining the exact mine from which a diamond originated.

$D M K$

The roles of primary kimberlitic and secondary Dwyka glacial sources in the development of alluvial and marine diamond deposits in southern Africa. J. M. Moore [j.moore@ru.ac.za] and A. E. Moore, Journal of African Earth Sciences, Vol. 38, No. 2, 2004, pp. 115-134.

It is well known that the source of most of the alluvial diamonds in southern Africa is a number of Cretaceous (145-65 million years [My]) kimberlites that have been deeply eroded. Diamonds liberated from these kimberlites have been concentrated into important deposits in major drainages (e.g., the Vaal River) in a variety of settings along their routes westward to the Atlantic Ocean. Less well known is the role glaciation played in the development of the alluvial deposits during the earlier Carboniferous/Permian periods (360-250 My).

The Dwyka glaciation (a 30 My period) occurred approximately 300-270 My ago when southern Africa was situated much closer to the South Pole. The authors provide convincing evidence that this glaciation eroded older kimberlites in certain areas (e.g., those where the Venetia and Premier mines were eventually developed) while also reworking diamond-bearing river sediments existing at the time in other areas. The glacial sediments (the Dwyka Group) themselves were later eroded, rereleasing diamonds into younger drainage systems. Some of these diamonds were transported to the west coast and incorporated into beach sediments. Thus, southern African diamonds found in modern river valleys or beach sediments likely had their origins from a number of different kimberlite sources. Application of this model could lead researchers to areas of southern Africa previously thought to be unpromising for diamonds (e.g., areas where the Dwyka Group has not been heavily eroded), and it might also help explain ore-grade and diamond-quality variability in current mining operations.

KAM

Spectroscopic studies on transition metal ions in colored diamonds. Y. Meng, M. Peng, and W. Chen, Spectroscopy and Spectral Analysis, Vol. 24, No. 7, 2004, pp. 769-774 [in Chinese with English abstract].

The forms and behaviors of transition-metal ions, such as $\mathrm{Ni}, \mathrm{Co}$, and $\mathrm{Fe}$, in both natural and synthetic diamonds have been extensively investigated, mainly because these elements are used as catalysts in the growth of diamonds by high-pressure, high-temperature (HPHT) techniques. Ni and Fe occur as interstitial or substitutional impurities in the diamond lattice, and form complexes with nitrogen in both natural and HPHT synthetic diamonds. Interstitial Co has been reported only in synthetic diamonds. In this article, the spectroscopic characteristics of the transition metals, and the forms in which they occur, were studied in six colored natural and synthetic diamonds (one light bluish gray diamond from Argyle, Australia; two "chameleon" diamonds from Indonesia; and three HРHT synthetic diamonds from Russia that were orange-yellow, light blue, and dark red).

SEM-EDS revealed $\mathrm{Ni}$ in all the samples. Co-related optical centers were reported for the first time in the chameleon diamonds, based on photoluminescence spectra. These spectra were similar to those recorded in annealed HPHT synthetic diamonds with Co-related optical centers. Ni-related optical centers and $\mathrm{H} 3$ centers also were detected in the chameleon diamonds, suggesting that they may have been subjected to natural irradiation 
and high-temperature annealing. EPR (electron paramagnetic resonance) spectroscopy revealed some nitrogenrelated peaks and some transition-metal elements (mainly Ni) related to fine structures in both the natural and the synthetic diamonds. The Argyle sample showed two Nirelated peaks centered at 785 and $872 \mathrm{~nm}$, as well as seven unrecognized peaks that may be assigned to a Ni-N complex.

Three historical "asteriated" hydrogen-rich diamonds: Growth history and sector-dependent impurity incorporation. B. Rondeau [rondeau@mnhn.fr], E. Fritsch, M. Guiraud, J.-P. Chalain, and F. Notari, Diamond and Related Materials, Vol. 13, No. 9, 2004, pp. 1658-1673.

Three diamond cleavage plates $(\sim 0.13-0.15 \mathrm{ct})$, each exhibiting symmetrical lobe- or petal-like color zones, were investigated to gain a better understanding of their growth structure and history. These historic type Ia diamonds, catalogued as part of the collection of the National Museum of Natural History in Paris between sometime before 1822 and 1844, were studied by the famous 19th century French mineralogists René-Just Haüy and Alfred Descloizeaux. For the present study, the samples were reexamined by spectroscopic, imaging, and luminescence techniques. Two of the samples displayed either gray or brown lobe-shaped sectors forming a three-fold arrangement in a near-colorless or light brown matrix, while the third exhibited dark brown lobes in a six-fold pattern in a light brown matrix. Each diamond is an example of contemporaneous growth of both cuboid (lobes) and octahedral (matrix) sectors, but with different amounts of nitrogen and hydrogen.

The various shapes of the lobed patterns in the three samples reflect a continuous variation in the relative growth rates of the two kinds of sectors. The UV-Vis spectra of all three samples displayed increasing absorption toward the UV region, which explains the gray or brown color. One sample also displayed a $415 \mathrm{~nm}$ band (the N3 center) in the octahedral sector and numerous weak absorption bands between 350 and $570 \mathrm{~nm}$ (due to $\mathrm{H}$ ) in the cuboid sector. IR spectra revealed enriched $\mathrm{H}$ and $\mathrm{N}$ concentrations in both sectors, but $\mathrm{H}$ was greater in the cuboid sectors (where it inhibited nitrogen aggregation), whereas $\mathrm{N}$ was greater in the octahedral sectors. Additional details of the IR and Raman spectra are presented, along with a discussion of the stages of incorporation of $\mathrm{N}$ and $\mathrm{H}$ during diamond formation. Hydrogen appeared to be incorporated in several different structural sites.

JES

\section{GEM LOCALITIES}

Cultured pearl resources and markets in China. H. Zhang and B. Zhang, Journal of Gems and Gemmology, Vol. 6, No. 4, 2004, pp. 14-18 [in Chinese with English abstract].
This article was written by authors from the National Gems \& Jewelry Information Center, Beijing, to provide producers and consumers with the latest statistics on the Chinese cultured pearl industry. Three main types of cultured pearls are being produced in China: saltwater, freshwater tissue-nucleated, and freshwater bead-nucleated.

The saltwater cultured pearl farms are located mainly in the provinces of Guangdong, Guangxi, and Hainan. Total production was $\sim 2$ tonnes in 2003, of which Guangdong produced the most (30 tonnes), followed by Guangxi (10 tonnes) and Hainan (2 tonnes).

The culturing region for Chinese freshwater tissuenucleated cultured pearls extends over six provinces along the Yangtze River. Zhejiang (32\%) is the most important, followed by Jiangsu (23\%), Hunan (17\%), Anhui (13\%), Hubei $(8 \%)$, and Jiangxi (7\%). Total production in 2003 was 1,400 tonnes. Zhuji in Zhejiang Province, and Weitang and Suzhou in Jiangsu Province, are the largest and most important trading centers for this type of cultured pearl. Jiangxi Province is the most important locality for freshwater bead-nucleated cultured pearls, with a total production in 2003 of 160 tonnes.

$T L$

Emeralds of the main world origins. E. P. Melnikov, A. V. Vasiliev, and G. N. Pilipenko, Gemological Bulletin, No. 11, 2004, pp. 7-16 [in Russian with short English abstract].

The gemological properties (S.G., R.I., dispersion, and birefringence) and mineral inclusions in emeralds from various worldwide deposits are summarized in three tables. Five main emerald-bearing belts and provinces are characterized: Colombian, Brazilian, South African, Uralian, and Central Asian. Also included are specific data for emeralds from Afghanistan, Australia, Austria, Madagascar, and Zambia.

In general, good-quality emeralds originate from two genetic types of deposits: a metasomatic greisen type in ultramafic rocks (Uralian), and a hydrothermal type characterized by veins in black shales and carbonate rocks (Colombian). The concentrations of minor elements differ between the types. Light green Uralian emeralds contain more Cr (up to 0.1 wt. \%) than do those from Colombia (0.01-0.06 wt.\%), but dark green emeralds from the Urals contain up to 0.33 wt. \% Cr, whereas comparable Colombian stones have up to 0.43 wt. $\% \mathrm{Cr}$. Fe and V concentrations also differ: up to 0.06 and $0.66 \mathrm{wt} \%$, respectively, in Colombian emeralds, compared to 0.54 and 0.1 wt. \%, respectively, in Uralian stones.

Visible-range absorption spectroscopy was performed on eight samples (along the ordinary and extraordinary rays), including one synthetic emerald containing only $\mathrm{Cr}$ as a chromophore. Two transmission windows were apparent in all these stones, one in the green region (480-540 nm) and one in the red region (>680 nm); a narrow $\mathrm{Cr}$ line near $680 \mathrm{~nm}$ was very characteristic of the extraordinary ray. The spectra of hydrothermal-type emer- 
alds from Afghanistan were close to that of the synthetic emerald. The Colombian stones tested were colored mainly by V; Cr lines near $800 \mathrm{~nm}$ were absent. The spectra of the Uralian emeralds did show Cr lines near $800 \mathrm{~nm}$, but absorption in the red region of the spectrum was stronger (such stones may show no reaction under the Chelsea filter). Emeralds from Zambia and Madagascar may show strong "aquamarine" lines near $800 \mathrm{~nm}$ and, in addition, a wide band near $650 \mathrm{~nm}$ (for the extraordinary ray only). These stones contain appreciable quantities of Fe and showed no reaction under the Chelsea filter.

BMS

Emeralds from the Panjshir Valley (Afghanistan). J. Fijal, W. Heflik, L. Natkaniec-Nowak, and A. Szczepaniak, Gemmologie: Zeitschrift der Deutschen Gemmologischen Gesellschaft, Vol. 53, No. 4, 2004, pp. 127-142.

Twelve emerald crystals from the Panjshir Valley in Afghanistan were studied using various gemological and mineralogical techniques. These emeralds were compared to those from around the world on the basis of results from macro- and microscopic observations; chemical, X-ray, and infrared spectroscopic analyses; and new oxygen isotope data. The emeralds from the Panjshir Valley probably formed from metasomatic alteration associated with regional metamorphism. They crystallized at temperatures in the range of $220-350^{\circ} \mathrm{C}$ in quartz-ankerite veins that intersect marbles and talc-carbonate schists. The low temperatures of formation and the oxygen isotope data suggest that the emeralds were formed by thermochemical reactions similar to those associated with the formation of the Brazilian, Colombian, and Pakistani (Swat-Mingora) emerald deposits.

$E F$

The Lened emerald prospect, Northwest Territories, Canada: Insights from fluid inclusion and stable isotopes, with implications for northern Cordilleran emerald. D. D. Marshall [marshall@sfu.ca], L. A. Groat, H. Falck, G. Giuliani, and H. Neufeld, Canadian Mineralogist, Vol. 42, No. 5, 2004, pp. 1523-1539.

In 1997, emerald and green beryl were found at the Lened property in the Northwest Territories, approximately 55 $\mathrm{km}$ northwest of the town of Tungsten in the Logan Mountains. Crystals up to $2.5 \mathrm{~cm}$ long (rarely of gem quality) formed in quartz-carbonate veins that are hosted within a fractured garnet-diopside skarn. Both the veins and the skarn are the result of contact metamorphism related to the intrusion of the mid-Cretaceous (93 My) Lened granitic pluton into Proterozoic sedimentary host rocks (shales and limestones).

The veins vary in thickness up to about $50 \mathrm{~cm}$, and nearly half of them contain some beryl or emerald. Chemical analyses by LA-ICP-MS indicate that the principal chromophore is $\mathrm{V}$, with little or no $\mathrm{Cr}$ (data from two crystals gave 830 and 1444 ppm V, and only 8 and 14 ppm $\mathrm{Cr}$. $\mathrm{A} \mathrm{CO}_{2}$-bearing aqueous brine is present within multiphase fluid inclusions along healed fractures in the emerald. Emerald formation is estimated to have occurred at pressures up to $320 \mathrm{MPa}$ and temperatures between 200 and $610^{\circ} \mathrm{C}$. Preliminary stable isotope data indicate that the emerald is derived from a magmatic source. The Cretaceous granitic rocks are believed to be the source of $\mathrm{Be}$, while V was extracted from the shales. This deposit has some geologic characteristics and conditions of formation similar to those at the Tsa Da Glisza (or Regal Ridge) emerald occurrence in the Yukon.

JES

Gemstones in Vietnam: A review. P. V. Long [vggc@fpt.vn], G. Giuliani, V. Garnier, and D. Ohnenstetter, Australian Gemmologist, Vol. 22, No. 4, 2004, pp. $162-168$

In the Luc Yen, Yen Bai, and Quy Chau areas of northern Vietnam, ruby and sapphire are hosted by primary deposits (metamorphic rocks) and in placers (associated with gem spinel and garnet). In southern Vietnam, the occurrence of sapphires is related to alkaline basalts, with blue sapphires being of economic significance. Here the sapphires are recovered from placer deposits along with gem zircon and peridot. Elsewhere in Vietnam, aquamarine, beryl, topaz, tourmaline, quartz (amethyst, citrine, and smoky), chalcedony, fluorite, opal, jadeite, nephrite, amazonite, and tektites are exploited to various degrees. Several types of cultured pearls are being produced in four provinces. Rubies, sapphires, and cultured pearls are presently the main gem materials of commercial importance in Vietnam. RAH

Migration of the Mendocino Triple Junction and the origin of titanium-rich mineral suites at New Idria, California. M. R. Van Baalen [mvb@harvard.edu], International Geology Review, Vol. 46, No. 8, 2004, pp. 671-692.

The discovery of cinnabar ore in the New Idria District of central California in 1851 began over a century of profitable mercury mining. This, combined with the subsequent exploration for oil in 1915, led to the discovery of several useful minerals including magnesite, chromite, various gems, and chrysotile (asbestos). Data on the formation and composition of Ti-rich mineral suites associated with the New Idria serpentinite are presented along with a new petrologic model for their formation. These peculiar minerals, which include Ti-rich andradite garnets and benitoite, underwent blueschist and lower greenschist metamorphism associated with the tectonic passage of the Mendocino Triple Junction and emplacement of the serpentinite $\sim 12$ million years ago. Previous workers had suggested that fluid migration introduced several of the elements necessary for the formation of the unusual mineral suites. However, more recent studies have shown that the solubilities of these elements (e.g., $\mathrm{Ti}, \mathrm{Al}$, and $\mathrm{Zr}$ ) are extremely low and would require fluid transport over long distances. 
The new model calls for isochemical metamorphism (i.e., no change in bulk composition is required) of preexisting pyroxenite veins, which contain all the required components necessary for the formation of Ti-rich mineral suites. The author suggests that benitoite, California's state gem, formed by metamorphism of blocks of Franciscan greenstone within the serpentinite at lower greenschist conditions.

Opals from Slovakia ("Hungarian" opals): A re-assessment of the conditions of formation. B. Rondeau [rondeau@mnhn.fr], E. Fritsch, M. Guiraud, and C. Renac, European Journal of Mineralogy, Vol. 16, No. 5, 2004, pp. 789-799.

Slovakian opals found in an andesitic host rock in the Dubník area, near Košice (which was part of Hungary until the end of World War I), are believed to have formed by water circulation during a tectonic event. Their physical properties were investigated by X-ray diffraction (opal-A), Raman spectroscopy (main peak at $437 \mathrm{~cm}^{-1}$ ), and scanning electron microscopy (relatively large silica spheres of $125-270 \mathrm{~nm}$ in diameter). Surprisingly, these properties are usually associated with opals found in sedimentary deposits, not volcanic rocks. Preliminary oxygen isotope data indicate a high $\delta^{18} \mathrm{O}$ value $(31 \%)$ for both Slovakian ("volcanic-type") and Australian ("sedimentary-type") opals, consistent with temperatures of formation of less than $45^{\circ} \mathrm{C}$. In contrast, Mexican ("volcanic-type") opal-CT shows a lower $\delta^{18} \mathrm{O}$ value $(13 \%$ ) that is consistent with formation at a higher temperature, possibly up to $190^{\circ} \mathrm{C}$. Thus, temperature is proposed as the control on the opal's physical properties, rather than the nature of the host rocks.

RAH

Pezzottaite $\mathrm{Cs}\left(\mathrm{Be}_{2} \mathrm{Li}\right) \mathrm{Al}_{2} \mathrm{Si}_{6} \mathrm{O}_{18}$ : A spectacular new berylgroup mineral from the Sakavalana pegmatite, Fianarantsoa province, Madagascar. F. C. Hawthorne, M. A. Cooper, W. B. Simmons, A. U. Falster, B. M. Laurs, T. Armbruster, G. R. Rossman, A. Peretti, D. Günter, and B. Grobéty, Mineralogical Record, Vol. 35, No. 5, 2004, pp. 369-378.

Pezzottaite is a pink to purplish red, Cs-rich beryl-group gem mineral that has been found in small quantities in Fianarantsoa Province, central Madagascar. It formed within a limited area of the pocket zone of the Sakavalana pegmatite as tabular crystals or irregularly shaped flat masses along with quartz, feldspar (cleavelandite and amazonite), tourmaline, and other minerals. This article presents a detailed description of this relatively new gem mineral, including information on its physical and optical properties, crystallographic and X-ray diffraction data, infrared spectra, and chemical composition. The mineral is uniaxial negative, with refractive indices of $\varepsilon=$ $1.601-1.611$ and $\omega=1.612-1.620$, and an observed density of $2.97 \mathrm{~g} / \mathrm{cm}^{3}$ (calculated $3.06 \mathrm{~g} / \mathrm{cm}^{3}$ ); hardness is 8 . It is inert to long- and short-wave UV radiation, and is dichroic in hand specimen $\mid \varepsilon=$ purplish pink to pinkish purple, and $\omega=$ pink-orange). Its relationship to other members of the beryl group is described. Several tens of kilograms of pezzottaite of varying quality were recovered at this locality in the late 2002, with little subsequent production.

JES

Pezzottait von Ambatovita, Madagaskar-eine abenteuerliche Entdeckung [Pezzottaite from Ambatovita, Madagascar-An adventurous discovery]. F. Pezzotta [fpezzotta@yahoo.com], Lapis, Vol. 30, No. 5, 2005, pp. 26-30.

In this article, the mineralogist after whom the new gem mineral pezzottaite is named, and who participated in its analysis and description, relates the history of pezzottaite from its first appearance in Antananarivo in November 2002 to its acknowledgment as a new mineral of the beryl group. He describes the flurry of activity following the discovery, the difficult conditions under which the stones were mined, the mineral paragenesis, and the geologic setting of the pezzottaite-bearing pegmatite. This same issue of Lapis also contains a detailed description of pezzottaite and its mineralogical properties ("Steckbrief Pezzottait," by R. Hochleitner and S. Weiss, pp. 9-11). Both articles contain lavish illustrations, a map, and crystal drawings.

Relationship between nanostructure and optical absorption in fibrous pink opals from Mexico and Peru. E. Fritsch [fritsch@cnrs-imn.fr], E. Gaillou, M. Ostroumov, B. Rondeau, B. Devouard, and A. Barreau, European Journal of Mineralogy, Vol. 16, No. 5, 2004, pp. 743-752.

Translucent pink opals from Mexico (Mapimí and the state of Michoacán) and Peru (Acarí area, near Arequipa) are opal-CT, containing $10-40 \%$ palygorskite, as demonstrated by X-ray diffraction, infrared spectroscopy, and S.G. measurements. As seen by electron microscopy, these opals have an unusual fibrous nanostructure (with bunches of fibers $20-30 \mathrm{~nm}$ in minimum diameter) related to the fibrous nature of the palygorskite crystals. This is in contrast to the usual perfect stacking of $150-300 \mathrm{~nm}$ silica spheres. A complex absorption centered at about $500 \mathrm{~nm}$ is the cause of the pink color. It is suggested that the absorption is due to quinone fossil products associated with the phyllosilicate fibers. The opal-CT-palygorskitequinone association is a geologic marker for a specific environment, presumably an ancient lake in a volcanic region.

$R A H$

Role of fluorine in the formation of the Mananjary emerald deposits (eastern Madagascar). B. Moine [moine@cict.fr], C. C. Peng, and A. Mercier, Comptes Rendus Geoscience, Vol. 336, No. 6, 2004, pp. 513-522.

The Mananjary emerald deposits are hosted by phlogopiterich rocks that formed through metasomatic alteration of 
ultrabasites at about $500^{\circ} \mathrm{C}$ and 2 kbar. F- and Be-rich fluids responsible for the emerald crystallization probably originated from granites and granitic pegmatites that were emplaced during the formation of the Ifanadiana-Angavo shear zone roughly 550-500 million years ago. Thermodynamic modeling explains the role of fluoride complexes in the transport of Be. The solubility of Be increases as the amount of $\mathrm{F}$ in aqueous solution increases. At the point of crystallization of an F-rich mineral (F-phlogopite in this case), the associated Be becomes unstable in solution and begins to crystallize minerals that are able to incorporate it into their structure (beryl in this case). Sufficient $\mathrm{Cr}$ within the ultrabasites enabled the formation of emerald.

\section{INSTRUMENTS AND TECHNIQUES}

In situ Raman spectroscopic investigations of the adorning gemstones on the reliquary Heinrich's Cross from the treasury of Basel Cathedral. I. Reiche [ina.reiche@culture.gouv.fr], S. Pages-Camagna, and L. Lambacher, Journal of Raman Spectroscopy, Vol. 35, No. 8-9, 2004, pp. 719-725.

A nondestructive study of the gems on Heinrich's reliquary cross, currently kept in Berlin at the Museum of Applied Arts (Kunstgewerbemuseum), was performed using a mobile Raman microspectrometer. Analyses were made with a fiber-optic attachment on the Raman analyzer directly in the museum, so there was no need to move the object. This cross, which dates from the first quarter of the 11th century, is considered one of the most precious relics in the treasury of Basel Cathedral. Sixty-eight "gems" are mounted on both the front and back of the cross. Most were found to be glass "paste" or varieties of quartz, although some garnets, sapphires, and rubies also were identified; 11 gems could not be identified unambiguously. It remains unclear whether the gem materials currently in the cross are the original ones-chosen mainly for their color and not necessarily for their value-or if they are later replacements for more valuable gems.

Several factors contributed to an overall lower quality of analyses than could be obtained with a conventional Raman microspectrometer in a laboratory. First, an instrument using fiber-optic coupling with a remote head has lower laser power, so it did not allow for the flexibility needed to work with several highly fluorescent gems. Second, older, historic samples often have irregular surfaces that result in poor analyses. Last, the authors were not allowed to clean the gems with solvents; therefore, organic or other residues could lead to additional peaks in the spectra. This study, while important for demonstrating the capabilities of mobile Raman spectroscopy, also shows the importance of coupling optical observations with spectroscopic results for gem identification.
The identification of carving techniques on Chinese jade. M. Sax [msax@thebritishmuseum.ac.uk], N. D. Meeks, C. Michaelson, and A. P. Middleton, Journal of Archaeological Science, Vol. 31, No. 10, 2004, pp. 1413-1428.

Jade carving in China dates from before 5000 BC. Thus far, the details of ancient jade-carving techniques have remained relatively unclear. This study resolves some of those issues. Methods developed to investigate known lapidary techniques used on quartz cylinder seals from the Near East were applied to eight Chinese nephrite jade artifacts. The artifacts were from three different historical periods: the Neolithic Hongshan and Liangzhu cultures (4th to 3rd millennia BC), the Western and Eastern Zhou dynasties (11th to 3rd centuries BC), and the Ming and Qing dynasties (14th to 20th centuries AD). The carving characteristics of the artifacts, observed using a binocular microscope and a scanning electron microscope, included surface texture, the shape in plan view, and the longitudinal depth of the engraved feature. The morphology of the surrounding surfaces was also considered.

Six carving techniques were identified: drilling, wheelcutting, sawing, flexible string sawing, riffling, and point or blade abrasion. Most of the artifacts retained traces of the original tool marks that appear to have been produced mainly during the secondary stages of shaping and incising the objects; weathering may be responsible for the absence of ancient tool marks on one sample. The techniques employed in this study have the potential to be applied to the development of a chronology of Chinese jade-carving techniques from the Neolithic to the modern era.

AI

Seeing stress in diamonds. K. Pope, Rough Diamond Review, No. 5, 2004, pp. 41-43.

Internal strain is an important factor in diamond fashioning, as localized strain complicates cutting and may even result in an unintended fracture. Inclusions, "knots," plastic deformation, or restrictions during crystal growth cause distortions in the crystal lattice (i.e., internal strain). This can be observed as anomalous birefringence, familiar to gemologists as the banded, colored patterns seen between crossed polarizers. This article describes how the time-consuming historic manual measurement and analysis of internal strain based on birefringence with the use of compensators (e.g., a quartz wedge or Berek compensator) has been superseded. Quantitative birefringence data can now be obtained in a matter of seconds with the Metripol device. This automated instrument consists of a motorized rotating polarizer, a circular analyzer assembly, a CCD (charge-coupled device) camera, and a computer with analytical software. This new imaging technique, in addition to helping reduce the risk of an unintended fracture during fashioning, has potential application in several areas of diamond research.

$D M K$ 


\section{SYNTHETICS AND SIMULANTS}

The identification properties of synthetic hydrothermal red, green, and blue beryl. M. B. Kopchikov and Yu. B. Shelementiev, Gemological Bulletin, No. 11, 2004, pp. 17-22 [in Russian with short English abstract].

A collection of 23 faceted samples $(0.05-0.30 \mathrm{ct})$ of hydrothermal synthetic beryl ( 12 red, 5 green, and 6 blue) were studied using a variety of standard and advanced techniques to determine their diagnostic properties. The crystals were grown at the Institute of Petrography and Mineralogy in Novosibirsk, Russia. This is the first time that the properties of synthetic beryl from this source have been reported.

No gas-liquid inclusions or color zoning were observed, contrary to what is frequently the case in natural beryl. An infrared peak at $3701 \mathrm{~cm}^{-1}$ was a diagnostic feature for all these hydrothermal synthetics; this peak is not found in natural beryl. There were also distinct differences in the visible-range absorption spectra of all three colors of synthetic beryl compared to their natural counterparts.

Nickel (0.1-0.4 wt. \% NiO) occurred in all the synthetic beryls. Copper was present in the green (0.92-1.27 wt. \% $\mathrm{CuO})$ and blue $(0.29-0.35$ wt. \% $\mathrm{CuO})$ varieties. S.G. and R.I. values were comparable to those found in natural beryl. When exposed to long-wave UV radiation, the synthetic aquamarines had weak white-yellow luminescence, and the synthetic red beryls had red luminescence of variable intensity; luminescence in the corresponding natural beryls is generally absent or very weak. UV fluorescence was absent in the green synthetic beryl samples due to their high Fe content.

$B M S$

The nature of channel constituents in hydrothermal synthetic emeralds. R. I. Mashkovtsev [rim@uiggm.nsc.ru] and S. Z. Smirnov, Journal of Gemmology, Vol. 29, No. 4, 2004, pp. 215-227.

Natural emeralds and hydrothermally grown synthetic emeralds have become increasingly difficult to separate due to improving techniques for growing the synthetics. Since their physical properties overlap, microscopic examination of their inclusions is important. However, if an emerald is "clean" or does not contain diagnostic inclusions, nondestructive techniques based on certain distinctive minor impurities can be used for identification. This article illustrates how IR spectroscopy and EDXRF analysis were used to separate Biron (Australian), Regency (Linde), and Tairus (Russian) hydrothermally grown synthetic emeralds from one other and from natural Ural Mountains emeralds. For example, hydrothermal synthetic emeralds are grown using ammonium halides in an acidic $(\mathrm{HCl})$ medium, so the detection of chlorine and ammonium molecules as a structural component confirms this origin. In Tairus synthetic emeralds, $\mathrm{Cu}$ and $\mathrm{Ni}$ form impurities that are derived from the walls of the steel autoclaves in which they grew. The amounts of $\mathrm{Cr}, \mathrm{V}$, and Fe (determined by EDXRF), as well as the type I and type II water peaks (determined by IR spectroscopy), also are useful parameters for distinguishing natural from hydrothermal synthetic emeralds from various sources. WMM

\section{TREATMENTS}

Meaning of ions diffusion coefficient in sapphire diffusion heat treatment. R. Yang, D. Yu, and J. Zhao, Journal of Tongii University (Natural Science), Vol. 32, No. 9, 2004, pp. 1145-1148 [in Chinese with English abstract].

Blue color enhancement of sapphire by surface-diffusion processes at high temperatures has been reported since the 1980s. However, most treatment processes are based on "trial and error." In this article, the diffusion coefficients of Fe and Ti ions in sapphire crystals calculated during various treatment conditions are presented. Colorless and light blue sapphires were treated with (unspecified) Fe- and Ti-containing chemicals in an aluminum oxide crucible at a temperature of $1,800-1,900^{\circ} \mathrm{C}$ for up to 72 hours at a Thai jewelry company. The thickness of the diffusion layer was measured from samples cut into $0.8 \mathrm{~mm}$ thick plates. The concentrations of Fe and Ti in different layers, starting from the outer surface of the samples, were determined by electron-microprobe analysis.

The diffusion coefficients of Fe and $\mathrm{Ti}$ in sapphire are mainly controlled by temperature, duration of the treatment, thickness of the diffused layer, and the initial concentrations of $\mathrm{Fe}^{2+}$ and $\mathrm{Ti}^{4+}$ ions in the chemical additives. However, at certain temperatures, the diffusion coefficients of Fe and Ti ions were essentially constant, regardless of variations in the duration. The diffusion coefficient of $\mathrm{Ti}$ ions was much greater than that of Fe ions, being $6.57 \times 10^{-9} \mathrm{~cm}^{2} \cdot \mathrm{s}^{-1}$ and $1.62 \times 10^{-9} \mathrm{~cm}^{2} \cdot \mathrm{s}^{-1}$, respectively. Using these coefficients in conjunction with specified temperatures and duration times, it is possible to control the thickness of the diffusion layer in sapphire. These coefficients may also be useful toward lightening dark colored sapphires, such as those from Shangdong, China.

A treatment study of Brazilian garnets. S. G. Eeckhout, A. C. S. Sabioni, and A. C. M. Ferreira, Journal of Gemmology, Vol. 29, No. 4, 2004, pp. 205-214.

Reports of gem treatments are widespread in the literature but very few have been published on garnets. This article reports on the enhancement of several types of mostly gem-quality Brazilian garnets (pyrope, almandine-pyrope, almandine-spessartine, and grossular), primarily from pegmatite and alluvial occurrences in the states of Minas Gerais and Rio Grande do Norte. The authors determined the enhancement response of these garnets to heat treatment in air, and in oxidizing (oxygen saturated), inert 
(argon saturated), and reducing (hydrogen saturated) atmospheres, at various temperatures $\left(600-1000^{\circ} \mathrm{C}\right)$ and durations (generally 4-24 hours). The response of pale yellow grossular to diffusion treatment $\left(900^{\circ} \mathrm{C}\right.$ for 44 hours) using oxides of $\mathrm{Fe}, \mathrm{Cr}$, and $\mathrm{Co}$ also was investigated.

Following heat treatment in both the oxidizing and inert atmospheres, almandine-spessartine and pyrope (containing $9.12 \mathrm{wt}$ \% FeO) became opaque and were coated with a "silvery skin," caused by the formation of hematite. The higher the iron content of the stone, the more noticeable the silvery luster. The iron-rich (i.e., almandine-containing) stones became opaque and had a burned, charcoal-like appearance after heating in air at $1,000^{\circ} \mathrm{C}$ for 4 hours or $900^{\circ} \mathrm{C}$ for 24 hours. Grossular samples turned orange after heating. No changes were observed in any sample heated in the reducing environment at $800^{\circ} \mathrm{C}$ for 4 hours.

Diffusion of Fe and Cr produced an orange layer on the grossular samples, whereas diffusion of Co produced a green layer. In general, longer treatment times and higher temperatures resulted in a greater thickness of the diffused color.

$W M M$

\section{MISCELLANEOUS}

Comments on Canada's national diamond strategy. R. Taplin [rtaplin@mccarty.ca] and T. Isaac, Journal of Energy «) Natural Resources Law, Vol. 22, No. 4, 2004, pp. 429-449.

Canada has become one of the world's primary diamond producers, which has prompted the federal and several provincial governments to draw up strategies that will (1) maximize benefits for Canadians; (2) develop cooperation between various governments, mining companies, and local populations; and (3) encourage investment and development in all sectors of the industry.

The primary policy dilemma facing Canada's industry is developing local diamond-manufacturing operations. The governments want to increase employment and local participation in the diamond industry, but mining companies claim that enforced supply to these operations results in diminished profits. The companies also claim that this deters future exploration and development. The current national policy is to make such supply agreements voluntary; however, the article cites an example of strong pressure from the government of the Northwest Territories to get BHP Billiton to offer $10 \%$ of its production from the Ekati mine to local operations. More stringent requirements could run afoul of the North American Free Trade Agreement and various other treaties and regulations.

The diamond industry and government also disagree over "Canadian Diamond" branding efforts. The government believes that a Canadian diamond origin could carry a premium in the market, while many in the industry do not. This has led to a debate over whether diamonds marked with that national origin must, indeed, be mined there; the Canadian government's definition says they must. [Editor's note: Under U.S. law, the "country of origin" for a faceted diamond is the country in which it was polished, not where it was mined; see Spring 2005 Gem News International, p. 71.] Mining regulations and aboriginal land rights also are discussed.

$R S$

Global governance and conflict diamonds: The Kimberley Process and the quest for clean gems. J. A. Grant [andgrant@dal.ca] and I. Taylor, The Round Table, Vol. 93, No. 375, 2004, pp. 385-401.

This paper recounts the early efforts of non-governmental organizations (NGOs) to pressure the world diamond industry into adopting controls to halt the trade in conflict diamonds. Two NGOs, Global Witness and Partnership Africa Canada, were instrumental in bringing this problem to world attention in the late 1990s. At the end of 1999, the NGOs began an awareness campaign among European consumers called Fatal Transactions. Shortly afterward, the U.S. Congress began debating legislation to ban conflict diamonds.

Early in 2000, a number of diamond-producing nations convened in Kimberley, South Africa, to discuss a series of controls on diamonds to help stop the conflict diamond trade. This was the beginning of the Kimberley Process (KP). The United Nations endorsed the KP in December of that year. The diamond industry formed the World Diamond Council to develop the tracking mechanism and self-regulation routines needed to put the KP into action.

The article concludes that, while the Kimberley Process and industry efforts show a commitment on the part of governments and the industry to stop conflict diamonds, challenges remain in the form of potentially compromised KP certificates of origin, the willingness of the trade to exercise due diligence, and the priorities of diamond-producing governments (particularly in areas with alluvial diamond mining).

$R S$

Improving your opal cutting. P. B. Downing, Lapidary Journal, Vol. 57, No. 11, 2004, pp. 25-28.

Four common problems encountered in opal cutting are addressed:

1. Making shoulders. For an opal to be properly set, it must have shoulders that allow the metal setting to solidly grip the stone. This requires a slight $\left(10-15^{\circ}\right)$ taper (narrower at the top) in the middle third of the shoulder; the bottom third of the shoulder is straight, and the top third curves into the dome.

2. Scratches and polish. The most efficient way to remove scratches is to sand across them with successively finer grits. Sanding with the scratches makes them broader and deeper. To bring out hard-to-see scratches during the medium sanding process, the stone should be paint- 
ed with a black marker and the ink wiped before it dries. The ink will be removed from a smooth surface but will remain in scratches. During the fine sanding stage, tiny scratches can be seen on the surface of dry samples by noting (a) without magnification, the reflection of the bulb of the cutting lamp; or (b) with $3 \times-10 \times$ magnification, straight lines with sharp definition. A good polish is essential to bring out the play-of-color. The smoother the surface, the more color will be returned to the eye.

3. Perfecting the dome. Domes on opals should have a smooth curvature with no flat spots. To achieve the best curvature, the opal should be sanded across flat spots with a medium grit followed by a fine grit.

4. Dome height. Low domes are best for stones with a highly directional color pattern, whereas higher domes are used for stones with a nondirectional or thick seam of color.

Analyzing the fire in opal rough is the first step to cutting any opal to bring that fire to the surface.

War, peace and diamonds in Angola: Popular perceptions of the diamond industry in the Lundas. J. Pearce, African Security Review, Vol. 13, No. 2, 2004, pp. 51-64.

This article examines the post-civil war diamond operations in two of Angola's diamond-producing provinces, Lunda Norte and Lunda Sul. After reviewing the effects of the country's civil war and the conflict diamonds issue, the author delves into the current conditions under which diamonds are extracted. The Lunda provinces, which had been a base for the UNITA rebel group during the country's civil war, now have three types of mining operations: garimpo, or "informal" hand digging; dredging, which employs machinery to extract and process diamond-bearing gravel from riverbeds; and formal mining by large companies.

According to Pearce, the garimpeiros who work the alluvial diamond deposits are now threatened by Angolan Armed Forces (FAA) seeking to expel them from all diamond-producing areas, particularly those areas of interest to the larger commercial concerns. Reports of brutality at the hands of soldiers are cited. Dredging operations are often carried out by foreign nationals, many from the neighboring Democratic Republic of the Congo, in league with FAA generals. In the formal sector, several large mining operations, particularly at Catoca, have been established, although locals have expressed anger at the mining companies and the Angolan government for policies which, they claim, favor foreign workers.
The author reports that there remains little meaningful employment in the two provinces, and most people still live by subsistence farming. Police and army officials extort funds, not just from diamond diggers, but also from health workers and traders. As a result, many of the provinces' inhabitants remain little better off than they were before and during the civil war.

Tackling conflict diamonds: The Kimberley Process Certification Scheme. C. Wright, International Peacekeeping, Vol. 11, No. 4, 2004, pp. 697-708.

The Kimberley Process Certification Scheme for rough diamonds is the first attempt by the international community to control illegal exploitation of natural resources. It is also the first agreement adopted with an equal partnership between governments, industry, and civil society groups.

The Kimberley Process (KP) was ratified by 54 governments, representatives of the diamond industry, and civil society groups in November 2002. It was put into effect in February 2003. Since then, several challenges to the process have arisen. In July 2003, 18 participating nations were asked to leave until they had adopted proper legislation and internal controls to meet the minimum standards for implementation. Six of these nations have subsequently rejoined. And, in early 2004, discrepancies between official diamond production in the Republic of the Congo and the actual diamond exports coming from that nation caused the KP chairman to withdraw its certification.

The Kimberley Process will receive a full review in 2006. Although the original reason for its adoption-to stop the trade in conflict diamonds-is less relevant because the civil wars have ended, there is an argument for retaining the system because of the potential for terrorists and criminals to launder or transport funds by diamond sales through illicit channels.

$R S$

Traditional gemstone cutting technology of Kongu region of Tamil Nadu. K. Rajan and N. Athiyaman, Indian Journal of History of Science, Vol. 39, No. 4, 2004, pp. 385-414.

The authors trace the long history of gem extraction and cutting in India's southern province of Tamil Nadu. The Kongu region was, and remains, the source for many gem varieties including beryl, corundum, quartz, and feldspar. Accounts of artisans working gems in the area date back to the 3rd century BC, and Pliny, in the 1st century AD, noted that the best beryls, of a "sea-green" color, mostly came from India.

The authors then discuss the villages of the region and describe in detail the techniques and equipment still employed today by traditional cutters in fashioning faceted stones and beads in those areas. 